Provided for non-commercial research and education use. Not for reproduction, distribution or commercial use.

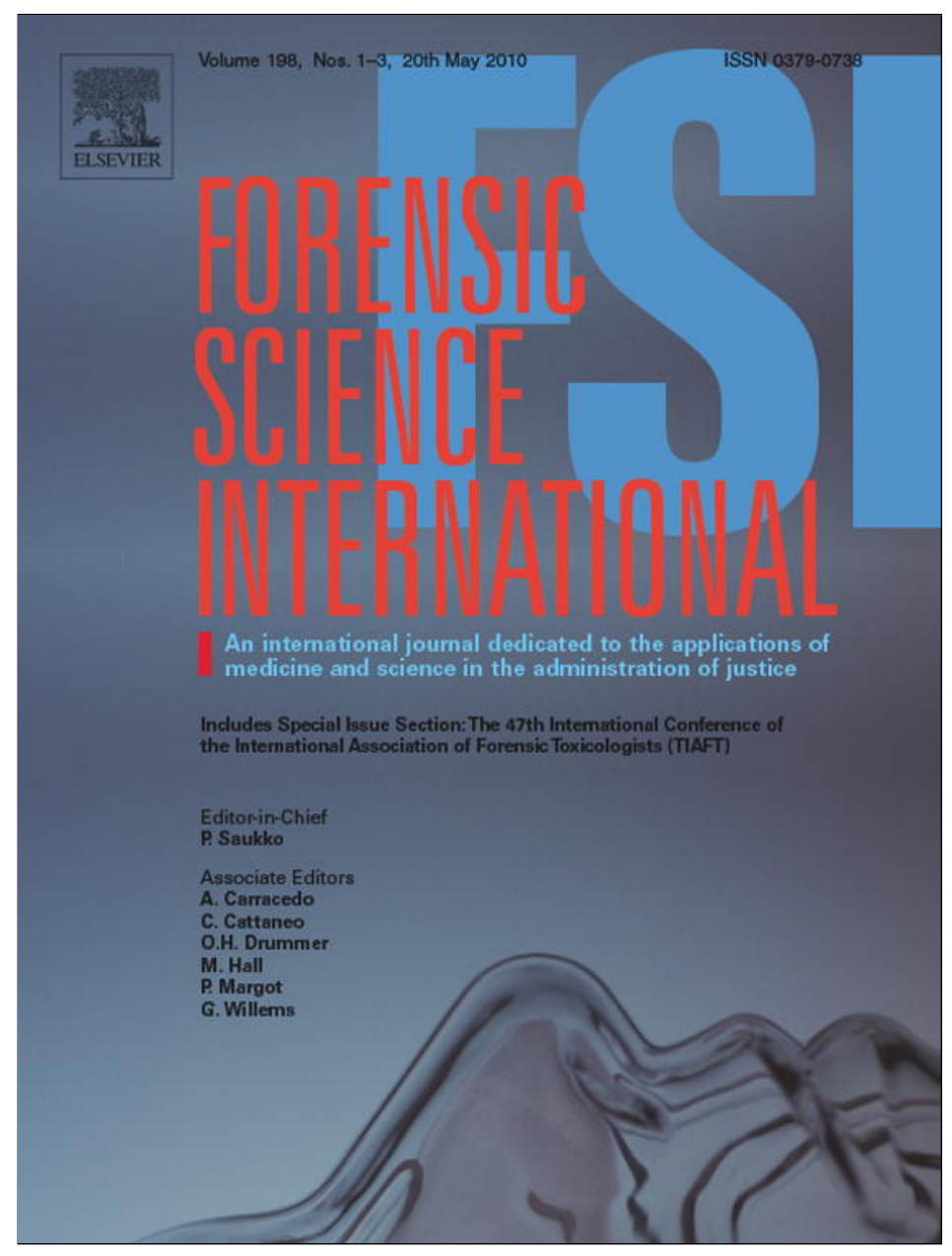

This article appeared in a journal published by Elsevier. The attached copy is furnished to the author for internal non-commercial research and education use, including for instruction at the authors institution and sharing with colleagues.

Other uses, including reproduction and distribution, or selling or licensing copies, or posting to personal, institutional or third party websites are prohibited.

In most cases authors are permitted to post their version of the article (e.g. in Word or Tex form) to their personal website or institutional repository. Authors requiring further information regarding Elsevier's archiving and manuscript policies are encouraged to visit:

http://www.elsevier.com/copyright 


\title{
Multiple isotope forensics of nitrate in a wild horse poisoning incident
}

\author{
Greg Michalski ${ }^{\mathrm{a}, *}$, Sam Earman $^{\mathrm{c}}$, Christa Dahman ${ }^{\mathrm{a}}$, Ronald L. Hershey ${ }^{\mathrm{b}}$, Todd Mihevc ${ }^{\mathrm{b}}$ \\ ${ }^{a}$ Department of Earth E Atmospheric Sciences, Department of Chemistry, Purdue University, West Lafayette, IN 47907-2051, United States \\ ${ }^{\mathrm{b}}$ Division of Hydrologic Sciences, Desert Research Institute, 2215 Raggio Pkwy, Reno, NV 89512-1095, United States \\ ${ }^{\mathrm{c}}$ Earth Sciences Department, Millersville University, Millersville, PA 17551, United States
}

\section{A R T I C L E INFO}

\section{Article history:}

Received 23 March 2009

Received in revised form 23 December 2009

Accepted 22 January 2010

Available online 16 March 2010

\section{Keywords:}

Nitrate

Isotope

Forensic

Nitrogen

Horse

\begin{abstract}
A B S T R A C T
Multiple stable isotope analysis can be a powerful technique in forensic sciences. Oxygen and nitrogen isotopes were used to determine the source of nitrate that was responsible for the poisoning deaths of 71 wild horses in the Nevada desert. The nitrate was present in a water-filled hole known as 'the Main Lake depression.' Nitrate from the Main Lake depression had $\delta^{18} \mathrm{O}$ and $\delta^{15} \mathrm{~N}$ values that were very positive $(+32 \%,+37 \%)$, and $\Delta^{17} \mathrm{O}$ values of approximately $+2 \%$. The isotopic data suggested that the most probable source of the nitrate was nitrification of nitrogen from horse manure and urine that had leached into the pond. The $\delta^{18} \mathrm{O}$ signal suggested that extreme evaporative concentration had occurred, resulting in toxic levels of nitrate accumulating in the Main Lake depression. The study demonstrates the utility of the multiple stable isotope analysis approach for characterizing sources of nitrate.
\end{abstract}

(c) 2010 Elsevier Ireland Ltd. All rights reserved.

\section{Introduction}

Stable isotope analysis is a useful tool in forensics because it can augment more conventional physical, chemical, and biological analyses [1]. Forensic scientists develop and test hypotheses based on evidence. These hypotheses are then evaluated and either supported or refuted. In criminal forensic investigations, hypothesis exclusion may result from comparing samples taken from a crime scene to samples recovered from a person or their belongings; determining the origin of a substance at a crime scene may be relevant to the investigation. In forensic geoscience, the motivation is often to exclude a sample of soil or rock from being related to a comparison sample by means of the sample's physical, chemical, or biological characteristics [2]. Stable isotope ratio mass spectrometry (IRMS) is an additional technique that can be utilized in this exclusion approach because it can often distinguish between different sources of the same compound. The ability to measure isotope ratios of more than one element in a single molecule (multiple isotope approach) allows refinement of stable isotope fingerprinting, and the more isotopes that can be measured, the more confidence in the identification of characteristics unique to the compound [1,3]. This technique has been employed to identify unique characteristics of a range of materials used in forensic investigations including explosives [4-6], drugs [7-9], and geochemical evidence [10-12]. This article details a

\footnotetext{
* Corresponding author. Tel.: +1 765494 3704; fax: +1 7654961210.

E-mail address: gmichals@purdue.edu (G. Michalski).
}

study of the use of stable isotopes of nitrogen and oxygen to test several nitrate source hypotheses in the death of 71 wild horses.

\section{Case history}

In July 2007, 71 wild horses from a herd of 250 were found dead in the northwestern Nevada Test and Training Range (NTTR) in southern Nevada (Fig. 1). Toxicology reports prepared by the California Animal Health and Food Safety Laboratory System indicated that high levels of nitrate $\left(\mathrm{NO}_{3}{ }^{-}\right)$and nitrite $\left(\mathrm{NO}_{2}{ }^{-}\right)$were the most probable cause of death, primarily because tests for botulin, anatoxin-a, and microcystins, and gas chromatography/ mass spectrometry screening for organic compounds, were all negative [13]. The carcasses were found near a water-containing depression in the Cactus Flat playa (hereafter referred to as the 'Main Lake depression') that was commonly used by the herd, suggesting that their sudden mortality could have been caused by rapid contamination of this water supply. $\mathrm{NO}_{3}{ }^{-}$concentration in water collected from the Main Lake depression shortly after the wild horse deaths was reported at $3670 \mathrm{mg} / \mathrm{L}$ (as N). $\mathrm{NO}_{2}{ }^{-}$in this sample was proportionally high at $50 \mathrm{mg} / \mathrm{L}$ (as N). Other ions were also present in markedly high concentrations including $2100 \mathrm{mg} / \mathrm{L}$ of chloride and $2100 \mathrm{mg} / \mathrm{L}$ of sulfate (Table 1 ).

After the wild horse deaths in 2007 were reported in the media, various public groups speculated that the $\mathrm{NO}_{3}{ }^{-}$responsible for the wild horse deaths resulted from the inappropriate dumping of urea deicing fluids, which had occurred previously in 1988. In this incident, 61 wild horses died near Air Force facilities at Cactus Flat by "ammonia toxicity due to excessive consumption of urea" [14] 


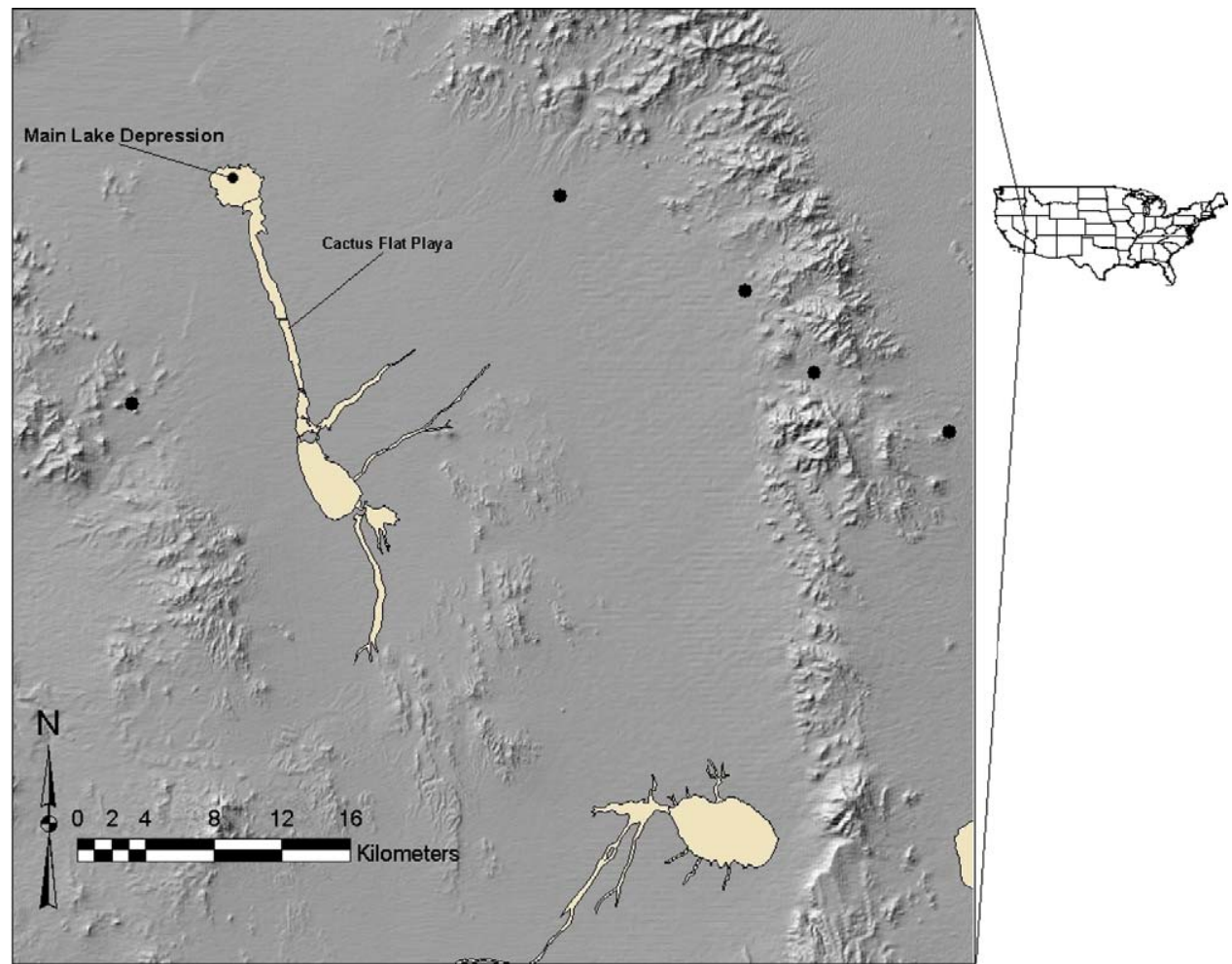

Fig. 1. Overview map showing the location of the Main Lake depression in the Cactus Flat Playa and spring samples collected in February 2008. Playas are shown in light yellow. Black circles show the location of springs sampled. (For interpretation of the references to color in this figure legend, the reader is referred to the web version of the article.)

Table 1

Analytical results from Main Lake depression water samples collected shortly after the 71 wild horse deaths in July 2007 at the Nevada Testing and Training Range. Concentrations in $\mathrm{mg} / \mathrm{L}$.

\begin{tabular}{|c|c|c|c|c|c|c|c|c|c|}
\hline Sample & $\mathrm{Ca}^{\mathrm{a}}$ & $\mathrm{Mg}^{\mathrm{a}}$ & $\mathrm{Na}^{\mathrm{a}}$ & $\mathrm{K}^{\mathrm{a}}$ & $\mathrm{Cl}^{\mathrm{b}}$ & $\mathrm{SO}_{4}{ }^{\mathrm{b}}$ & $\mathrm{NO}_{3}{ }^{\mathrm{a}}$ & $\mathrm{NO}_{2}{ }^{\mathrm{a}}$ & TDS $^{\mathrm{b}}$ \\
\hline Shallow & 23 & 1.7 & 47 & 6.4 & NA & NA & 5 & ND & NA \\
\hline Deep & 81 & 53 & 4800 & 153 & 2100 & 2100 & 3670 & 50 & 31,000 \\
\hline
\end{tabular}

NA: not analyzed; ND: non-detect; TDS: total dissolved solids.

a California Animal Health \& Food Safety Laboratory System.

b Test America.

that was rinsed from a truck forming puddles of highly concentrated urea. In soils, urea is degraded by microbes into ammonia $\left(\mathrm{NH}_{4}{ }^{+}\right)$[16], and nitrifying soil organisms can then convert the $\mathrm{NH}_{4}{ }^{+}$into $\mathrm{NO}_{3}{ }^{-}$. In 1988 , the wild horses died after drinking from the urea laced puddles. At that time, urea was commonly used as a runway deicer in the U.S. because it is much less corrosive than other deicers such as sodium chloride. More recently, the use of urea deicers has been extremely rare, because other deicers are cheaper, more effective, and have lower environmental impact [15-17]. The Air Force discontinued the use of urea deicers in 1996 [18]. Isotope analysis of the $\mathrm{NO}_{3}{ }^{-}$in the Main Lake depression was used as a forensic approach to determine its source.

\subsection{Nitrate isotope background}

$\mathrm{NO}_{3}{ }^{-}$is a compound that is found naturally, but is also produced synthetically by humans in large quantities, and is toxic at high concentrations. Synthetic $\mathrm{NO}_{3}{ }^{-}$includes nitric acid and nitrate salts, the latter being common fertilizers, including ammonium nitrate. Nitric acid and nitrate salts are also key ingredients used in the production of commercial and home-made explosives. For example, the explosive used in the 1995 bombing of the Alfred P. Murrah Federal Building in Oklahoma City was composed primarily of agricultural-grade ammonium nitrate. A significant portion of atmospheric $\mathrm{NO}_{3}{ }^{-}$is derived from the photochemical oxidation of nitrogen oxides produced during combustion (autos, power plants, etc.). The oxidation process forms gaseous nitric acid and aerosol nitrate salts, which are then deposited on surfaces through wet and dry deposition. Biologic transformation of $\mathrm{NH}_{4}^{+}$into $\mathrm{NO}_{3}{ }^{-}$, nitrification, is the largest source of natural $\mathrm{NO}_{3}{ }^{-}$. Nitrification can occur in nearly all soils, sediments, and waters where significant amounts of $\mathrm{NH}_{4}{ }^{+}$are available and conditions are sufficiently aerobic. From a forensic standpoint, $\mathrm{NO}_{3}{ }^{-}$, the presence of which is usually determined by ion chromatography, can be derived from any of these sources. As a result, using typical chemical analyses, natural sources of $\mathrm{NO}_{3}{ }^{-}$ cannot be distinguished from synthetic sources, and if synthetic $\mathrm{NO}_{3}{ }^{-}$is present, the mode of production cannot be determined.

The isotopic characterization of $\mathrm{NO}_{3}{ }^{-}$is a potential means of distinguishing between $\mathrm{NO}_{3}{ }^{-}$sources, allowing for hypothesis exclusion when hypotheses involving different $\mathrm{NO}_{3}{ }^{-}$sources can be developed. $\mathrm{NO}_{3}{ }^{-}$contains nitrogen, which has two stable isotopes $\left({ }^{14} \mathrm{~N},{ }^{15} \mathrm{~N}\right)$, and oxygen, which has three $\left({ }^{16} \mathrm{O},{ }^{17} \mathrm{O},{ }^{18} \mathrm{O}\right)$. Both nitrogen and oxygen isotopes can be used individually, or in tandem, to characterize $\mathrm{NO}_{3}{ }^{-}$. Isotopic compositions are reported 


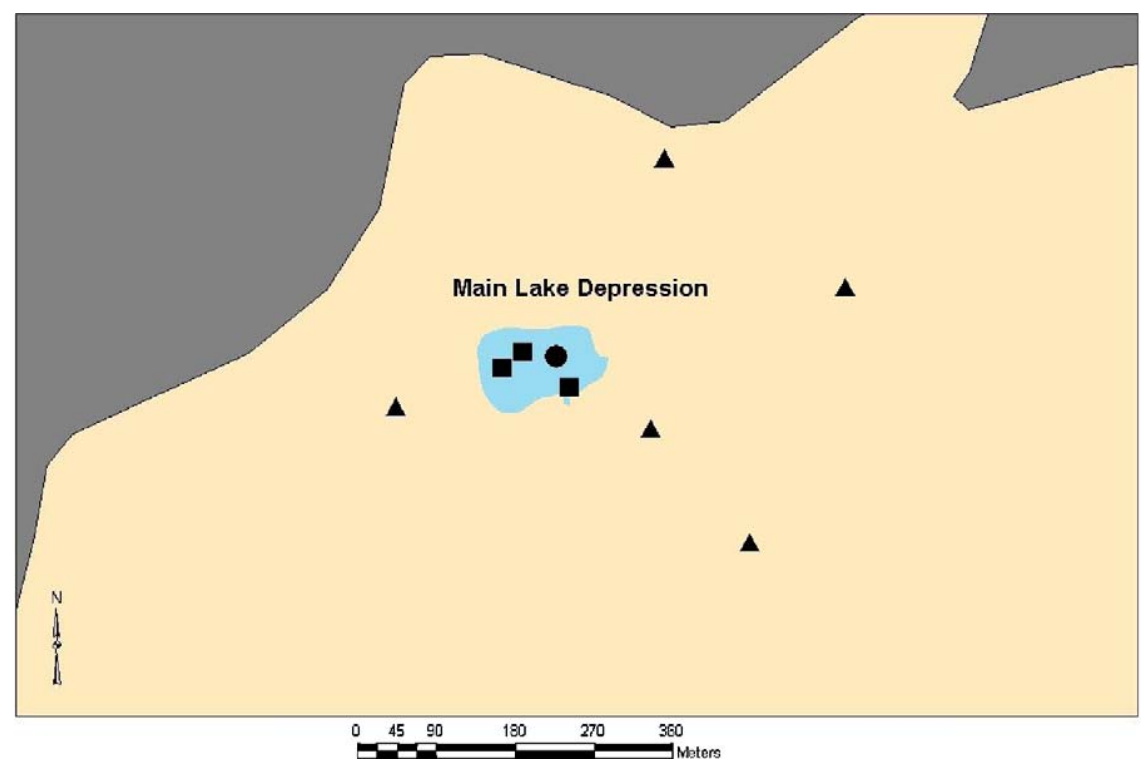

Fig. 2. Map showing the location of the Main Lake depression in the Cactus Flat Playa and location of water (circle), depression sediments (squares), and alluvial sediments (triangles) collected in February 2008. The Cactus Flat playa is show in light yellow, the Main Lake depression is shown in blue. (For interpretation of the references to color in this figure legend, the reader is referred to the web version of the article.)

as a difference between the ratio of the minor isotope to the major isotope in a sample and that of a standard reference material. The change in abundances, noted as delta $(\delta)$, is typically small, so the difference is reported as per mil ( 1 per 1000 , symbolized \%). For nitrogen,

$\delta^{15} \mathrm{~N}(\%)=\frac{\left({ }^{15} \mathrm{~N} /{ }^{14} \mathrm{~N}\right)_{\text {sample }}-\left({ }^{15} \mathrm{~N} /{ }^{14} \mathrm{~N}\right)_{\text {standard }}}{\left({ }^{15} \mathrm{~N} /{ }^{14} \mathrm{~N}\right)_{\text {standard }}} \times 1000$

There are similar equations for determining the $\delta$ values of the oxygen isotopes ${ }^{17} \mathrm{O}$ and ${ }^{18} \mathrm{O}$. The standard for nitrogen is atmospheric $\mathrm{N}_{2}$, and the standard for oxygen is Vienna Standard Mean Ocean Water or VSMOW. The $\delta^{15} \mathrm{~N}, \delta^{18} \mathrm{O}$, and $\delta^{17} \mathrm{O}$ values of $\mathrm{NO}_{3}{ }^{-}$vary depending on the source material and the process of formation. The $\delta$ values can also be altered by partial loss of $\mathrm{NO}_{3}{ }^{-}$ from a reservoir. For example, denitrification, the partial conversion of $\mathrm{NO}_{3}{ }^{-}$into $\mathrm{N}_{2}$ by microorganisms, is known to enrich the $\delta^{15} \mathrm{~N}$ and $\delta^{18} \mathrm{O}$ values of the residual $\mathrm{NO}_{3}{ }^{-}$. The typical ranges of $\delta$ values for $\mathrm{NO}_{3}{ }^{-}$derived from various sources and the isotopic fractionation by partial loss are discussed below.

\section{Materials and methods}

Samples of water and sediment were collected from the Main Lake depression in February 2008 (Fig. 2) to investigate the origin of the high $\mathrm{NO}_{3}{ }^{-}$in the Main Lake depression in July 2007. In addition, samples of alluvial sediment were collected near the Main Lake depression (Fig. 2) and water samples were collected from springs in adjacent mountain ranges (Fig. 1). Water samples were collected in $7.6 \mathrm{~L}$ polypropylene containers to obtain sufficient $\mathrm{N}$ to allow isotopic analysis. Most water was filtered through a $0.2-\mu \mathrm{m}$ cartridge filter prior to collection. The two Main Lake depression water samples contained too much fine sediment for $0.2-\mu \mathrm{m}$ field filtration, so they were collected after filtration through a $0.45-\mu \mathrm{m}$ cartridge filter. In the field, samples were stored in insulated coolers to maintain a temperature as close to $4{ }^{\circ} \mathrm{C}$ as possible. After transport to the Desert Research Institute in Reno, NV, samples were stored in a refrigerator until transferred to the Purdue Stable Isotope facility at Purdue University for isotopic analysis.

The Main Lake depression was originally excavated for a U.S. Department of Energy/Sandia National Laboratories project approximately 20 years ago. The depression collects winter precipitation and runoff from surrounding mountain ranges and has been used by wildlife as a consistent source of drinking water throughout the year, even during the dry season when other standing water is absent on the valley floor. However, because of below-normal precipitation in 2006 and 2007, water in the Main Lake depression had mostly evaporated and was only approximately $0.3 \mathrm{~m}$ deep when the wild horses were found dead.

Complete stable isotope analysis of $\mathrm{NO}_{3}{ }^{-}$requires that it be in the form of silver nitrate $\left(\mathrm{AgNO}_{3}\right)[18,19] . \mathrm{NO}_{3}{ }^{-}$was extracted from the samples, then concentrated and purified using ion exchange resin techniques [19]. The $\mathrm{NO}_{3}{ }^{-}$was eluted from the anion exchange columns using $3 \mathrm{M} \mathrm{HBr}$ and converted to $\mathrm{AgNO}_{3}$ by spatula addition of excess $\mathrm{Ag}_{2} \mathrm{O}_{(s)}$, which precipitates all anions except sulfate. Sulfate was removed with the addition of $\mathrm{BaCl}_{2}$ and the resulting precipitate removed by filtration. Residual cations were exchanged for $\mathrm{H}^{+}$using cation exchange resin, and the resulting $\mathrm{HNO}_{3}$ was converted to $\mathrm{AgNO}_{3(\mathrm{aq})}$ with the addition of $\mathrm{Ag}_{2} \mathrm{O}_{(\mathrm{s})}$ by weight. Ion chromatography was performed to confirm that only $\mathrm{NO}_{3}{ }^{-}$was present in the purified solution. After this was verified, the solution was freeze dried to $\mathrm{AgNO}_{3(\mathrm{~s})}$. Oxygen isotope analysis was performed using the $\mathrm{AgNO}_{3}$ thermal decomposition method [20], and the resulting $\mathrm{O}_{2}$ was measured on a dual-inlet isotope ratio mass spectrometer (Thermo Delta $\mathrm{V}$ ). The method has a $\delta^{18} \mathrm{O}$ precision

Table 2

Nitrogen and oxygen isotopic data for nitrate in water and alluvial sediment samples and oxygen isotopic data in water samples collected in February 2008 at the Nevada Testing and Training Range. Units in per mil (\%).

\begin{tabular}{llll}
\hline Sample & $\delta^{15} \mathrm{~N} \mathrm{NO}_{3}$ & $\delta^{18} \mathrm{O} \mathrm{NO}_{3}$ & $\Delta^{17} \mathrm{O} \mathrm{NO}_{3}$ \\
\hline Main Lake depression water shallow & +27.4 & +25.1 & +1.88 \\
Main Lake depression water deep & +38.6 & +31.4 & +1.76 \\
Cedar Wells Spring water & +9.61 & +14.5 & +1.69 \\
Rose Spring water & +7.58 & +20.0 & +1.98 \\
Alluvial Sediment 4 & +18.8 & +18.1 & +0.46 \\
Alluvial Sediment 5 & $\mathrm{ND}$ & +25.5 & +2.42 \\
Alluvial Sediment 6 & +16.0 & +16.1 & +1.36 \\
Alluvial Sediment 7 & +17.5 & +14.23 & +2.24 \\
Alluvial Sediment 8 & +20.3 & +15.1 & +2.63 \\
Alluvial Sediment 11 & +12.08 & +2.10 \\
\hline
\end{tabular}

NA: not analyzed; ND: non-detect. 


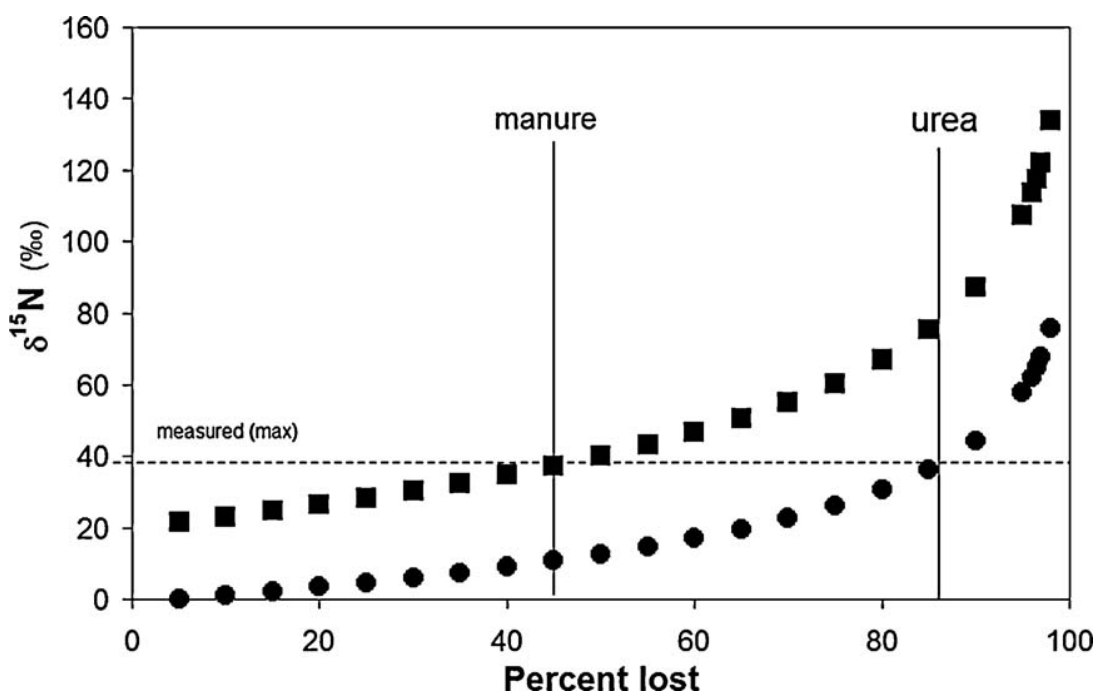

Fig. 3. Rayleigh distillation model of ${ }^{15} \mathrm{~N}$ enrichment for $\mathrm{N}$ compounds with different initial ${ }^{15} \mathrm{~N}$ compositions. Urea or natural fixation (circles) would require nearly 90 percent loss to match the observed $\delta^{15} \mathrm{~N}$ values of $\mathrm{NO}_{3}{ }^{-}$in the Main Lake depression, whereas manure (squares) would require approximately 45 percent of the $\mathrm{N}$ to be lost.

of $\pm 1 \%$ and a $\Delta^{17} \mathrm{O}$ precision of $\pm 0.3 \%$ ( $\Delta^{17} \mathrm{O}$ is defined below). $\delta^{15} \mathrm{~N}$ of the $\mathrm{AgNO}_{3}$ was analyzed using the standard thermal conversion/elemental analysis IRMS technique [21].

\section{Results and discussion}

\subsection{Nitrogen isotope values}

$\mathrm{NO}_{3}{ }^{-}$from the February 2008 NTTR samples was highly enriched in ${ }^{15} \mathrm{~N}$. $\mathrm{NO}_{3}{ }^{-}$extracted from surrounding alluvial sediments had $\delta^{15} \mathrm{~N}$ values of $+18 \pm 2 \%$, whereas spring waters had slightly lower $\delta^{15} \mathrm{~N}$ of +7.6 and $+9.6 \%$, and the Main Lake depression water samples had $\mathrm{NO}_{3}{ }^{-} \delta^{15} \mathrm{~N}$ values that were highly enriched at +28 and $+37 \%$ (Table 2). The $\delta^{15} \mathrm{~N}$ values for the alluvial sediment $\mathrm{NO}_{3}{ }^{-}$are enriched relative to typical desert soils, but similar $\delta^{15} \mathrm{~N}$ values of $\mathrm{NO}_{3}{ }^{-}$are seen in clay-rich soils in the Mojave Desert near the Barstow syncline [22]. The spring water $\mathrm{NO}_{3}{ }^{-} \delta^{15} \mathrm{~N}$ values are similar to Mojave ground water $\left(\delta^{15} \mathrm{~N}+6\right.$ to $+11 \%$ [ [23]. Atmospheric $\mathrm{NO}_{3}{ }^{-}$from the southwestern United States has $\delta^{15} \mathrm{~N}$ values close to zero. Therefore, while the alluvial sediment and spring $\delta^{15} \mathrm{~N}$ values are within the range of natural desert $\mathrm{NO}_{3}{ }^{-}$found in the southwestern U.S., the Main Lake depression $\mathrm{NO}_{3}{ }^{-} \delta^{15} \mathrm{~N}$ values are atypical. To test the hypothesis that urea deicers were the source of $\mathrm{NO}_{3}{ }^{-}$in the Main Lake depression water, a sample of commercial urea was analyzed, yielding a $\delta^{15} \mathrm{~N}$ value of $-1.0 \pm 0.23 \%(n=9)$. Most synthetic $\mathrm{N}$ compounds have $\delta^{15} \mathrm{~N}$ close to zero because they are synthesized by $\mathrm{H}_{2}$ reduction of atmospheric $\mathrm{N}_{2}(0 \%)$ at high temperature (Haber-Bosch process), with negligible isotopic fractionation during the production process [24]. The large difference between the $\delta^{15} \mathrm{~N}$ values of the urea and the Main Lake depression $\mathrm{NO}_{3}{ }^{-}$suggests that the Main Lake depression $\mathrm{NO}_{3}{ }^{-}$was not derived from urea deicers. However, none of the observed natural sources had $\delta^{15} \mathrm{~N}$ as high as the Main Lake depression $\mathrm{NO}_{3}{ }^{-}$, thus the source of the high $\mathrm{NO}_{3}{ }^{-}$was not readily apparent, requiring additional assessment.

The ${ }^{15} \mathrm{~N}$ enrichment of Main Lake depression $\mathrm{NO}_{3}{ }^{-}$relative to alluvial sediments and springs has three potential explanations. The first is isotopic enrichment from denitrification, which leads to increases in $\delta^{15} \mathrm{~N}$ values as a function of $\mathrm{NO}_{3}{ }^{-}$loss $[25,26]$. The second is preferential loss of ${ }^{14} \mathrm{~N}$ during volatilization of $\mathrm{NH}_{4}{ }^{+}$ when organic matter or urea decomposes. This process would have increased the $\delta^{15} \mathrm{~N}$ values in the residual $\mathrm{NH}_{4}{ }^{+}$, which could then have been nitrified. Third, the high $\delta^{15} \mathrm{~N}$ values could be the result of input from a source of $\mathrm{NH}_{4}{ }^{+}$that is isotopically heavy and was subsequently nitrified. The first hypothesis is unlikely as the $\delta^{15} \mathrm{~N}$ enrichment would also result in a significant loss of $\mathrm{NO}_{3}{ }^{-}$, which is contrary to the observed high $\mathrm{NO}_{3}{ }^{-}$concentrations (also discussed in the oxygen isotope section). Volatilization of $\mathrm{NH}_{4}{ }^{+}$cannot be discounted, but the high degree of ${ }^{15} \mathrm{~N}$ enrichment would be accompanied by decreases in alluvial sediment $\mathrm{NH}_{4}{ }^{+}$concentrations, and thus less available $\mathrm{NH}_{4}{ }^{+}$for nitrification. A standard Rayleigh model can be used to estimate this loss [27]

$\delta^{15} \mathrm{~N}=\delta^{15} \mathrm{~N}_{0}+\varepsilon \ln (f)$

where $\delta^{15} \mathrm{~N}_{0}$ is the initial $\mathrm{NH}_{4}{ }^{+} \delta^{15} \mathrm{~N}$ value, $\varepsilon$ is the enrichment factor for volatilization, which is approximately $-20 \%$ for $\mathrm{NH}_{4}{ }^{+}$ [28], and $f$ is the fraction of the original $\mathrm{NH}_{4}{ }^{+}$remaining. If the remaining $\mathrm{NH}_{4}{ }^{+}$is then nitrified and this is the source of the Main Lake depression $\mathrm{NO}_{3}{ }^{-}$, then the $\delta^{15} \mathrm{~N}$ value of the $\mathrm{NO}_{3}{ }^{-}$would have the same $\delta^{15} \mathrm{~N}$ value as the residual $\mathrm{NH}_{4}{ }^{+}$. Fig. 3 shows a Rayleigh model using different initial $\delta^{15} \mathrm{~N}$ values of the various $\mathrm{NO}_{3}{ }^{-}$ sources and the observed Main Lake depression $\mathrm{NO}_{3}{ }^{-}$as the model constraint. The model suggests that if the Main Lake depression $\mathrm{NO}_{3}{ }^{-}$was derived from synthetic urea $\left(\delta^{15} \mathrm{~N}_{0}=-1 \%\right.$ ), then approximately 90 percent of the synthetic urea would have to have decomposed and volatilized to match the Main Lake depression's $\delta^{15} \mathrm{~N}$ value. The most probable explanation for the high $\delta^{15} \mathrm{~N}$ of the Main Lake depression $\mathrm{NO}_{3}{ }^{-}$is nitrification of manure $\left(\delta^{15} \mathrm{~N}_{0}=20 \%\right)$. Feed lot and manure $\mathrm{NO}_{3}{ }^{-}$typically have values between +10 and $+25 \%$ o 28,30$]$. The manure may have undergone additional enrichment from volatilization of approximately 50 percent of the total $\mathrm{NH}_{4}{ }^{+}$to generate the $+37 \%$ value observed in the Main Lake depression water's dissolved $\mathrm{NO}_{3}{ }^{-}$ (Fig. 3).

\subsection{Oxygen isotope values}

Oxygen isotopes in $\mathrm{NO}_{3}{ }^{-}$can shed additional light on source and sink processes affecting the nitrogen in a given system [29,3133]. The $\delta^{18} \mathrm{O}$ of natural soil $\mathrm{NO}_{3}{ }^{-}$is derived from the two main sources, atmospheric deposition $\left(\mathrm{NO}_{3}{ }^{-}\right.$atm $)$and nitrification by microbes $\left(\mathrm{NO}_{3}{ }^{-}\right.$bio $)$and can be represented by

$\delta^{18} \mathrm{ONO}_{3}^{-}=x \delta^{18} \mathrm{ONO}_{3}^{-}$atm $+(1-x) \delta^{18} \mathrm{ONO}_{3}^{-}$bio

where $x$ is the mole fraction of $\mathrm{NO}_{3}{ }^{-}$atm and $1-x$ is the mole fraction of $\mathrm{NO}_{3}{ }^{-}$bio. The $\mathrm{NO}_{3}{ }^{-}$bio is derived from the oxidation of 


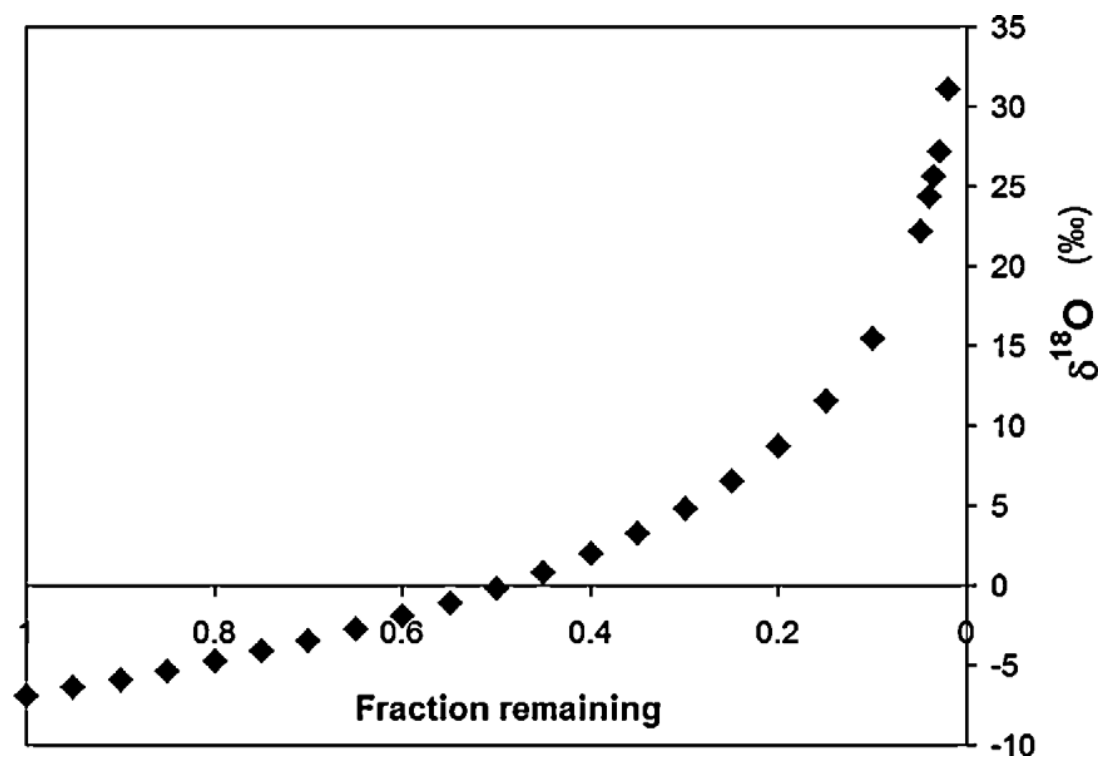

Fig. 4. Water $\delta^{18} \mathrm{O}$ enrichment based on an initial water $\delta^{18} \mathrm{O}$ from a local spring at the NTTR, an enrichment factor of $8 \%$, and using a Rayleigh model. To match the $\mathrm{NO}_{3}{ }^{-} \delta^{18} \mathrm{O}$ value observed in the Main Lake depression requires over 90 percent evaporation of the original water.

$\mathrm{NH}_{4}{ }^{+}$. Eq. (3) contains three unknowns: $x, \delta^{18} \mathrm{O} \mathrm{NO}_{3}{ }^{-}$atm, and $\delta^{18} \mathrm{O}$ $\mathrm{NO}_{3}{ }^{-}$bio. The two $\delta^{18} \mathrm{O}$ unknowns can be expanded and estimated. For $\mathrm{NO}_{3}{ }^{-}$bio, two of the three oxygen atoms acquired by $\mathrm{N}$ during nitrification are derived from ambient water, with the remaining oxygen atom derived from $\mathrm{O}_{2}$, so the value of $\delta^{18} \mathrm{O} \mathrm{NO}_{3}{ }^{-}$bio can be written as

$\delta^{18} \mathrm{ONO}_{3}^{-}$bio $=(2 / 3) \delta^{18} \mathrm{OH}_{2} \mathrm{O}+(1 / 3) \delta^{18} \mathrm{OO}_{2}+\varepsilon$

where the $\delta^{18} \mathrm{O}$ of $\mathrm{O}_{2}$ is assumed to have a constant value of $+23 \%$ [34] and $\varepsilon$, the enrichment factor occurring during nitrification, is often taken as zero (or self cancelling when comparing nitrification samples from the same region). Water $\delta^{18} \mathrm{O}$ values can be highly variable in time and space because $\delta^{18} \mathrm{O}$ values in precipitation vary depending on season, temperature, and a storm's point of origin (e.g., Pacific Northwest versus Gulf of Mexico) [35]. In addition, subsequent evaporation of rainfall from soils, streams, or lakes alters the initial precipitation $\delta^{18} \mathrm{O}$ values via equilibrium and kinetic isotope fractionation; the kinetic fractionation is amplified in low-humidity desert regions as compared to humid areas $[27,36]$. Estimating the $\delta^{18} \mathrm{O}$ of the water presents a challenge because it requires knowing what water is used during the nitrification process. If nitrification is a continual process that is limited only by water and $\mathrm{NH}_{4}{ }^{+}$availability, then nitrification can utilize water from different parts of seasonal and evaporative cycles, thus incorporating variable water $\delta^{18} \mathrm{O}$ values into the bulk $\mathrm{NO}_{3}{ }^{-}$bio.

For $\mathrm{NO}_{3}{ }^{-}$atm, the most reliable $\delta^{18} \mathrm{O}$ data suggest a range of values between +60 and $+80 \%$, with a yearly average of approximately $+70 \%$ o $[29,33,37,38]$. Current understanding of $\mathrm{NO}_{3}{ }^{-}$atm formation suggests that its $\delta^{18} \mathrm{O}$ value is set by the mass balance between oxygen sources that are incorporated in $\mathrm{NO}_{3}{ }^{-} \mathrm{atm}$ during photochemical oxidation of $\mathrm{NO}_{\mathrm{x}}\left(\mathrm{NO}_{3}{ }^{-}\right.$atm precursors). These oxygen sources are primarily $\mathrm{O}_{3}$ and tropospheric water vapor [37]. The proportion of water-vapor oxygen assimilated into $\mathrm{NO}_{3}{ }^{-}$atm changes seasonally, and the $\delta^{18} \mathrm{O}$ values of water vapor vary depending on the regional precipitation $\delta^{18} \mathrm{O}$, local evapotranspiration, and temperature. Thus, the high variability in water $\delta^{18} \mathrm{O}$ values over the course of a year introduces a high degree of uncertainty in the mass-balance Eq. (3).
It is possible to reduce this uncertainty by using the ${ }^{17} \mathrm{O}$ excess, which is quantified by

$\Delta^{17} \mathrm{O}=\delta^{17} \mathrm{O}-0.52 \delta^{18} \mathrm{O}$

For normal mass-dependent kinetic and equilibrium isotopic fractionation, $\delta^{17} \mathrm{O} \cong 0.52 \delta^{18} \mathrm{O}$ [38], thus for kinetic processes such as nitrification and evaporation or equilibrium processes such as condensation (precipitation), the $\Delta^{17} \mathrm{O}$ value is zero. Positive $\Delta^{17} \mathrm{O}$ values arise from mass-independent fractionation, primarily during $\mathrm{O}_{3}$ formation, or from mass-balance reactions involving ozone [37-40]. Since $\mathrm{NO}_{3}{ }^{-}$atm obtains oxygen atoms from ozone during its formation, positive $\Delta^{17} \mathrm{O}$ values observed in $\mathrm{NO}_{3}{ }^{-}$atm originate from this mass-balance transfer [37]. Contributions of ozone to $\mathrm{NO}_{3}{ }^{-}$atm formation are less variable and are independent of changing $\delta^{18} \mathrm{O}$ of tropospheric water vapors. These considerations allow formulization of a second $\mathrm{NO}_{3}{ }^{-}$mass-balance equation similar to (3), but in terms of $\Delta^{17} \mathrm{O}$

$$
\Delta^{17} \mathrm{ONO}_{3}^{-}=x \Delta^{17} \mathrm{ONO}_{3}^{-} \text {atm }+(1-x) \Delta^{17} \mathrm{ONO}_{3}^{-} \text {bio }
$$

Since meteoric waters and $\mathrm{O}_{2}$ used in nitrification have $\Delta^{17} \mathrm{O}$ values of approximately $0 \%$, and the $\Delta^{17} \mathrm{O} \mathrm{NO}_{3}{ }^{-}$bio term is zero, so $x$ can readily be solved for

$$
x=\frac{\Delta^{17} \mathrm{O} \mathrm{NO}_{3}^{-}}{\Delta{ }^{17} \mathrm{O} \mathrm{NO}_{3}^{-} \mathrm{atm}}
$$

Here, $\Delta^{17} \mathrm{O} \mathrm{NO}_{3}{ }^{-}$is the measured value for a soil or water sample and $\Delta^{17} \mathrm{O} \mathrm{NO}_{3}{ }^{-}$atm is the atmospheric value, which can be derived from measurements or modeling of regional atmospheric chemistry. The range in observed $\Delta^{17} \mathrm{O} \mathrm{NO}_{3}{ }^{-}$atm values is +20 to $+30 \%$, with annual average in the southwestern U.S. approximately $+23 \%$ [41].

The $\Delta^{17} \mathrm{O}$ values of $\mathrm{NO}_{3}{ }^{-}$in the NTTR alluvial sediment samples were $+2.3 \pm 0.2 \%$ o $(n=5)$, with one value outside this range at $+1.4 \%$ (Table 2). Spring water $\Delta^{17} \mathrm{O}$ values were significantly lower at $+0.46 \%$. The $\Delta^{17} \mathrm{O}$ values in $\mathrm{NO}_{3}{ }^{-}$from the deep and shallow Main Lake depression water samples were $+1.8 \%$ and $+1.9 \%$, respectively. Using these values, the fraction of $\mathrm{NO}_{3}{ }^{-}$derived from nitrification can be estimated using Eq. (6), and the $\delta^{18} \mathrm{O}$ of waters used during nitrification can be evaluated. For example, in the deep Main Lake 
depression sample $\left(\Delta^{17} \mathrm{O}=+1.8 \%\right), 8$ percent of the $\mathrm{NO}_{3}{ }^{-}$is unprocessed residual $\mathrm{NO}_{3}{ }^{-}$atm $(+1.8 \% /+23 \%=0.08)$ and 92 percent is from nitrification. Using the moles fractions of 0.08 for $\mathrm{NO}_{3}{ }^{-}$atm and 0.92 for $\mathrm{NO}_{3}{ }^{-}$bio, a seasonal average $\mathrm{NO}_{3}{ }^{-}$atm $\delta^{18} \mathrm{O}$ of $+70 \%$, the observed $\mathrm{NO}_{3}{ }^{-} \delta^{18} \mathrm{O}$ values in the deep Main Lake depression sample of $+31.4 \%$, and Eqs. (3) and (4), the $\delta^{18} \mathrm{O}$ value of the water used during the nitrification is $+28 \%$.

The measured water $\delta^{18} \mathrm{O}$ value of the Main Lake depression water (sampled the year following the horse deaths) was $+1.98 \%$, whereas springs in adjacent mountain ranges had water $\delta^{18} \mathrm{O}$ value of $-6.92 \%$. This indicates that the nitrification in the Main Lake depression the previous year must have occurred during the last stages of evaporation, since evaporation of locally derived water is the only reasonable explanation for the presence of water with such a high $\delta^{18} \mathrm{O}$ value. Since the depression water is evaporating into low-humidity desert air, a Rayleigh distillation model is approximately valid. Using the deep Main Lake depression sample as input water $\delta^{18} \mathrm{O}(-6.92 \%)$ and a water enrichment factor of $9 \%$ at $28^{\circ} \mathrm{C}$, the Rayleigh model suggests nitrification occurred when the depression water had undergone 95 percent evaporation (Fig. 4). The shallow Main Lake depression sample, which has a calculated nitrification water $\delta^{18} \mathrm{O}$ value of $21 \%$, yields similar results.

Important points are (1) an accurate measure of the relative mole fractions of the two potential sources of the Main Lake depression $\mathrm{NO}_{3}{ }^{-}$using the $\Delta^{17} \mathrm{O}$ measurements can be derived, and (2) from this, the water $\delta^{18} \mathrm{O}$ value and the timing of nitrification can be deduced. In a general sense, the mole ratio of the two sources depends on environmental conditions, but in desert regions, the nitrification source is limited by the availability of water and $\mathrm{NH}_{4}{ }^{+}$. Given a limited geographic setting, the water availability can be assumed constant so that any change in the ratio is caused by another source of available $\mathrm{N}$. The hypothesis that the 2007 wild horse deaths resulted from the dumping of urea into the Main Lake depression can be tested by looking for changes in the $\mathrm{NO}_{3}{ }^{-}$bio $/ \mathrm{NO}_{3}{ }^{-}$atm ratio relative to that found in undisturbed alluvial sediments. Alluvial sediments had an average $\Delta^{17} \mathrm{O}$ value of $+2.3 \%$, giving a $\mathrm{NO}_{3}{ }^{-}$bio $/ \mathrm{NO}_{3}{ }^{-}$atm ratio of 9 versus a ratio of 11.5 in the Main Lake depression water (this is a 27 percent increase in the deep Main Lake depression sample's $\mathrm{NO}_{3}{ }^{-}$bio over the alluvial sediments $[(11.5-9) / 9])$. The $\Delta^{17} O$ evidence indicates the Main Lake depression and surrounding alluvial sediments are already dominated by nitrification, so the 27-percent increase is really only recording a change in the nitrification contribution from 90 to 92 percent. Given uncertainties in the analytical technique (0.3\%), and assumptions in the model, it does not appear that a significant amount of anthropogenic $\mathrm{NH}_{4}{ }^{+}$(synthetic urea) was nitrified, but the nitrate source was nitrification of the horse's manure under highly evaporative conditions.

\section{Acknowledgement}

This research was funded by the U.S. Department of the Interior, Bureau of Land Management.

\section{References}

[1] S. Benson, C. Lennard, P. Maynard, C. Roux, Forensic applications of isotope ratio mass spectrometry-a review, Forensic Sci. Int. 157 (2006) 1-22.

[2] H.G. Walls, Forensic, Science: An Introduction to Scientific Crime Detection, Praeger, New York, 1974.

[3] W. Meier-Augenstein, R.H. Liu, Forensic applications of isotope ratio mass spectrometry, in: Y. Yinon (Ed.), Advances in Forensic Applications of Mass Spectrometry, CRC Press, Boca Raton, 2004, pp. 149-180.

[4] C.M. Lock, W. Meier-Augenstein, Investigation of isotopic linkage between precursor and product in the synthesis of a high explosive, Forensic Sci. Int 179 (2008) 157-162.

[5] G. Pierrini, S. Doyle, C. Champod, F. Taroni, D. Wakelin, C. Lock, Evaluation of preliminary isotopic analysis $\left({ }^{13} \mathrm{C}\right.$ and $\left.{ }^{15} \mathrm{~N}\right)$ of explosives: a likelihood ratio approach to assess the links between semtex samples, Forensic Sci. Int. 167 (2007) 43-48.

[6] R.R., McGuire, C.A. Velsko, C.G. Lee, E. Raber, The use of post detonation analysis of stable isotope ratios to determine the type and production process of the explosives involved, UCRL-ID-113275, 1993, Lawrence Livermore National Laboratory.

[7] S. Sewenig S. Fichtner, T. Holdermann, G. Fritschi, H. Neumann, Determination of $\delta^{13} \mathrm{C}$ (V-PDB) and $\delta^{15} \mathrm{~N}$ (AIR) values of cocaine from a big seizure in Germany by stable isotope ratio mass spectrometry, Isot. Environ. Health Stud. 43 (2007) 275280.

[8] N. NicDaeid, W. Meier-Augenstein, Feasibility of source identification of seized street drug samples by exploiting differences in isotopic composition at natural abundance level by GC/MS as compared to isotope ratio mass spectrometry (IRMS), Forensic Sci. Int. 174 (2008) 259-261.

[9] J.H. Liu, W.F. Lin, M.P. Fitzgerald, S.C. Saxena, Y.N. Shieh, Possible characterization of samples of cannabis-sativa 1 by their carbon isotopic distributions, J. Forensic Sci. 24 (1979) 814-816

[10] F. Roelofse, U.E. Horstmann, A case study on the application of isotope ratio mass spectrometry (IRMS) in determining the provenance of a rock used in an alleged nickel switching incident, Forensic Sci. Int. 174 (2008) 63-66.

[11] K. Pye, S.J. Blott, D.J. Croft, J.F. Carter, Forensic comparison of soil samples: assessment of small-scale spatial variability in elemental composition, carbon and nitrogen isotope ratios, color, and particle size distribution, Forensic Sci. Int. 163 (2006) 59-80.

[12] G.J. Bowen, L.I. Wassenaar, K.A. Hobson, Global application of stable hydrogen and oxygen isotopes to wildlife forensics, Oecologia 143 (2005) 337-348.

[13] California Animal Health \& Food Safety Laboratory System, Accession Summary Report T0701789, 2007.

[14] B. Stager, A. Ruegamer, Tonopah Test Ranges Death of 61 Wild Horses, Memo to Bureau of Land Management District Manager, Las Vegas, 1988.

[15] D.T. Ireland, New salt based highway deicers with improved anti-corrosive properties, in: F.M. D'Itri (Ed.), Chemical Deicers and the Environment, Lewis Publishers, Boca Raton, 1992, pp. 403-420.

[16] V.M. Moran, L.A. Abron, L.W. Weinberger, A comparison of conventional and alternate deicers: an environmental impact perspective, in: F.M. D'Itri (Ed.) Chemical Deicers and the Environment, Lewis Publishers, Boca Raton, 1992. pp. 341-362.

[17] R.D. Sills, P.A. Blakeslee, The environmental impact of deicers in airport atormwater runoff, in: F.M. D'Itri (Ed.), Chemical Deicers and the Environment, Lewis Publishers, Boca Raton, 1992, pp. 323-340.

[18] U.S. Air Force Center for Environmental Excellence, Air Force Aircraft and Airfield Deicing/Anti-icing, PRO-ACT Fact Sheet Update, May 1998, TI-16621.

[19] S.R. Silva, C. Kendall, D.H. Wilkison, A.C. Ziegler, C.C.Y. Chang, R.J. Avanzino, A new method for collection of nitrate from fresh water and the analysis of nitrogen and oxygen isotope ratios, J. Hydrol. 228 (2000) 22-36.

[20] G. Michalski, J. Savarino, J.K. Böhlke, M. Thiemens, Determination of the tota oxygen isotopic composition of nitrate and the calibration of a $\Delta^{17} \mathrm{O}$ nitrate reference material, Anal. Chem. 74 (2002) 4989-4993.

[21] C.C.Y. Chang, S.R. Silva, C. Kendall, G. Michalski, S. Wankel, K.L. Casciotti, Preparation and analysis of nitrogen-bearing compounds in water for stable isotope ratio measurement, in: P.A. DeGroot (Ed.), Handbook of Stable Isotope Analytical Techniques, vol. 1, Elsevier, Amsterdam, 2004, pp. 305-347.

[22] J.K. Böhlke, G.E. Ericksen, K. Revesz, Stable isotope evidence for an atmospheric origin of desert nitrate deposits in northern Chile and southern California, USA Chem. Geol. 136 (1997) 135-152.

[23] J.N. Densmore, J.K. Bohlke, Use of nitrogen isotopes to determine sources of nitrate contamination in two desert basins in California, Int. Assoc. Hydr. Sci. Wallingford (2000) 63-73.

[24] A.S. Bateman, S.D. Kelly, Fertilizer nitrogen isotope signatures, Isot. Environ. Health Stud. 43 (2007) 237-247.

[25] D.J.Z. Chen, K.T.B. MacQuarrie, Correlation of $\delta^{15} \mathrm{~N}$ and $\delta^{18} \mathrm{O}$ in $\mathrm{NO}_{3}{ }^{-}$during denitrification in groundwater, J. Environ. Eng. Sci. 4 (2005) 221-226.

[26] A. Mariotti, J.C. Germon, P. Hubert, P. Kaiser, R. Letolle, A. Tardieux, P. Tardieux, Experimental-determination of nitrogen kinetic isotope fractionation - some principles - illustration for the denitrification and nitrification processes, Plant Soil 62 (1981) 413-430.

[27] R.E. Criss, Principles of Stable Isotope Distribution, Oxford University Press, New York, 1999.

[28] P. Hogberg, Tansley review No $95-{ }^{15} \mathrm{~N}$ natural abundance in soil-plant systems, New Phytol. 137 (1997) 179-203.

[29] C. Kendall, Tracing nitrogen sources and cycling in catchments, in: C. Kendall, J.J. McDonnell (Eds.), Isotope Tracers in Catchment Hydrology, Elsevier Science, Amsterdam, 1998, pp. 519-576.

[30] P. Dijkstra, O.V. Menyailo, R.R. Doucett, S.C. Hart, E. Schwartz, B.A. Hungate, C and $\mathrm{N}$ availability affects the ${ }^{15} \mathrm{~N}$ natural abundance of the soil microbial biomass across a cattle manure gradient, Eur. J. Soil Sci. 57 (2006) 468-475.

[31] A. Amberger, H.L. Schmidt, Natural isotope content of nitrate as an indicator of its origin, Geochim. Cosmochim. Acta 51 (1987) 2699-2705.

[32] R. Aravena, M.L. Evans, J.A. Cherry, Stable isotopes of oxygen and nitrogen in source identification of nitrate from septic systems, Ground Water 31 (1993) 180-186.

[33] W. Durka, E.D. Schulze, G. Gebauer, S. Voerkelius, Effects of forest decline on uptake and leaching of deposited nitrate determined from ${ }^{15} \mathrm{~N}$ and ${ }^{18} \mathrm{O}$ measurements, Nature 372 (1994) 765-767.

[34] P. Kroopnick, H. Craig, Atmospheric oxygen. Isotopic composition and solubility fractionation, Science 175 (1972) 54-55. 
[35] G.J. Bowen, B. Wilkinson, Spatial distribution of $\delta^{18} \mathrm{O}$ in meteoric precipitation, Geology 30 (2002) 315-318.

[36] H. Craig, L.I. Gordon, Y. Horibe, Isotopic exchange effects in evaporation of water. 1. Low-temperature experimental results, J. Geophys. Res. 68 (1963) 5079.

[37] G. Michalski, Z. Scott, M. Kabiling, M. Thiemens, First measurements and modeling of $\Delta{ }^{17} \mathrm{O}$ in atmospheric nitrate, Geophys. Res. Lett. 30 (2003) 1870.

[38] D.A. Burns, C. Kendall, Analysis of $\delta^{15} \mathrm{~N}$ and $\delta^{18} \mathrm{O}$ to differentiate $\mathrm{NO}_{3}{ }^{-}$sources at two watersheds in the Catskill Mountains of New York, Water Resour. Res. 38 (2002) 1051.
[39] M.F. Miller, I.A. Franchi, M.H. Thiemens, T.L. Jackson, A. Brack, G. Kurat, C.T. Pillinger, Mass-independent fractionation of oxygen isotopes during thermal decomposition of carbonates, Proc. Natl. Acad. Sci. U.S.A. 99 (2002) 10988-10993.

[40] M.H. Thiemens, J. Savarino, J. Farquhar, H. Bao, Mass-independent isotopic compositions in terrestrial and extraterrestrial solids and their applications, Acc. Chem. Res. 34 (2001) 645-652.

[41] G. Michalski, T. Meixner, M. Fenn, L. Hernandez, A. Sirulnik, E. Allen, M. Thiemens, Tracing atmospheric nitrate deposition in a complex semiarid ecosystem using $\Delta^{17}$ O, Environ. Sci. Technol. 38 (2004) 2175-2181. 